\author{
Notaire \\ e-ISSN: 2655-9404 \\ p-ISSN: 2721-8376 \\ Vol. 4 No. 2, Juni 2021 \\ DOI: $10.20473 /$ ntr.v4i2.27168
}

Article history: Submitted 1 May 2021; Accepted 20 May 2021; Available online 1 June 2021.

\title{
Akta Penegasan Perjanjian Perkawinan Kaitannya dengan Pemenuhan Prinsip Publisitas
}

\author{
Raden Ajeng Cendikia Aurelie Maharani \\ raden.ajeng.cendikia-2019@fh.unair.ac.id \\ Universitas Airlangga
}

\begin{abstract}
In the Marriage Agreement to bind the third party, then the marriage agreement must meet the principle of publicity, that is, by registered or recorded. Registration of marriage agreement for Muslims at KUA Kecamatan / PPN LN, while for non-Muslims are recorded at the Department of Population and Civil Registration. One of the conditions for recording a marriage agreement is the marriage agreement act. The form of marriage agreement for Muslims is regulated in Article 22 paragraph (2) Permenag RI No. 20/2019, the word "done in front of a notary" in question is an authentic act. As for non-Muslims, the form of marriage agreement is regulated in Circular Letter 472.2/5876/Dukcapil which does not follow MK Decision No. 69/PUU-XII/2015 which states that the marriage agreement is made in the form of a Notary deed, this is stated in the first point in the circular. In the making of marriage agreements there is often a misunderstanding by making an affirmation act from a letter under hand. The result of the research obtained is that the marriage agreement made under hand and then made a affirmation act by a notary then the affirmation act does not meet the principle of publicity as determined in the Marriage Law, because in one of the conditions of validity of the marriage agreement must be registered with the registrar bind the third party until the act of affirmation of the marriage agreement does not bind the third party. This research is a study of normative juridical law with the method of Legislative approach and conceptual approach.
\end{abstract}

Keywords: Affirmation Deed; Marriage Agreement; Publicity Principle.

\begin{tabular}{|c|}
\hline \\
\hline $\begin{array}{l}\text { Dalam Perjanjian perkawinan agar mengikat pihak ketiga, maka perjanjian perkawinan harus } \\
\text { memenuhi prinsip publisitas, yaitu dengan didaftarkan atau dicatatkan. Pencatatan perjanjian } \\
\text { perkawinan bagi yang beragama Islam pada KUA Kecamatan/PPN LN, sedangkan bagi yang } \\
\text { beragamaNon-Islam dicatatkandiDinasKependudukandanPencatatanSipil. Bentukperjanjian } \\
\text { perkawinan bagi yang beragama Islam diatur dalam Pasal } 22 \text { ayat (2) Permenag RI No. 20/2019 } \\
\text { dilakukan dihadapan notaris yang dimaksud adalah akta autentik. Sedangkan bagi yang } \\
\text { beragama non-Islam bentuk Perjanjian perkawinan diatur dalam Surat Edaran } 472.2 / 5876 / \\
\text { Dukcapil yang menindaklanjuti Putusan MK No. 69/PUU-XII/2015 yang menyebutkan } \\
\text { bahwa Perjanjian perkawinan dibuat dalam bentuk akta Notaris, hal ini tercantum dalam } \\
\text { point kesatu dalam surat edaran tersebut. Dalam pembuatan perjanjian perkawinan masih } \\
\text { seringkali terdapat kesalahpahaman dengan dibuatkannya akta penegasan atas perjanjian } \\
\text { perkawinan yang dibuat di bawah tangan. Adapun hasil penelitian yang diperoleh bahwa } \\
\text { Perjanjian perkawinan yang dibuat di bawah tangan kemudian dibuatkan akta penegasan oleh } \\
\text { notaris maka akta penegasan tersebut tidak memenuhi prinsip publisitas sebagaimana yang } \\
\text { telah ditentukan dalam UU Perkawinan, karena dalam salah satu syarat keabsahan perjanjian } \\
\text { perkawinan harus dilakukan pendaftaran pada pegawai pencatatan perkawinan agar mengikat } \\
\text { pihak ketiga sehingga akta penegasan perjanjian perkawinan yang tersebut tidak mengikat } \\
\text { pihak ketiga. Penelitian ini merupakan penelitian normatif dengan metode pendekatan yang } \\
\text { dipergunakan adalah pendekatan perundang-undangan dan pendekatan konseptual. } \\
\text { Kata Kunci: Akta Penegasan; Perjanjian Perkawinan; Prinsip Publisitas. }\end{array}$ \\
\hline
\end{tabular}




\section{Pendahuluan}

Dalam BW, perjanjian perkawinan diatur dalam Buku Kesatu Bab VII yang dimulai dari Pasal 139 sampai Pasal 154. Dalam Pasal 147 BW menyebutkan bahwa perjanjian perkawinan dilakukan sebelum perkawinan dilangsungkan dan harus dibuat dalam suatu akta notaris. Akan tetapi, pengaturan perjanjian perkawinan tidak lagi mengacu pada ketentuan dalam BW tetapi pada UU Perkawinan. Menurut Pasal 29 UU Perkawinan, perjanjian perkawinan dibuat pada waktu atau sebelum perkawinan dalam bentuk tertulis dan disahkan oleh Pegawai Pencatat Perkawinan, kemudian dengan adanya Putusan Mahkamah Konstitusi Nomor 69/PUU-XIII/2015 terdapat perubahan bahwa Perjanian perkawinan dibuat pada waktu, sebelum dilangsungkan atau selama dalam ikatan perkawinan kedua pihak atas persetujuan bersama dapat mengadakan perjanjian tertulis yang disahkan oleh pegawai pencatat perkawinan atau notaris, setelah mana isinya berlaku juga terhadap pihak ketiga sepanjang pihak ketiga tersangkut.". Kesepakatan perkawinan terhadap pemisahan harta bersama meskipun telah dibuat secara tertulis, namun kesepakatan perkawinan tersebut tidak dicatat, maka Perjanjian tersebut tidak sah menurut hukum. ${ }^{1}$

Suatu perjanjian perkawinan agar mengikat dengan pihak ketiga maka harus memenuhi prinsip publisitas. Prinsip Publisitas sangat diperlukan dalam perjanjian perkawinan, wujud prinsip pubisitas pada perjanjian perkawinan adalah pencatatan perjanjian perkawinan. Dalam suatu Pencatatan Perjanjian perkawinan sebagaimana telah diatur dalam Peraturan Menteri Agama Republik Indonesia Nomor 20 Tahun 2019 Tentang Pencatatan Pernikahan (Selanjutnya disebut Permenag RI No. 20/2019), bagi yang beragama Islam pencatatan perjanjian perkawinan harus dibuat dalam bentuk akta notaris dan dicatatkan pada Kepala KUA Kecamatan/PPN LN. Hal ini pula dicantumkan dalam Surat Edaran 472.2/5876/Dukcapil Tentang Pencatatan Pelaporan Perjanjian Perkawinan bagi

1 Sarizal, Darmawan, dan Mahfud Abdullah, 'Kedudukan Perjanjian Kawin Terhadap Pemisahan Harta Bersama Setelah Dilaksanakannya Perkawinan Kaitannya Dengan Putusan Mahkamah Konstitusi Nomor 69/PUU-XIII/2015 Tentang Waktu Pembuatan Perjanjian Kawin'(2019) 3 Syiah Kuala Law Journal.[301]. 
yang beragama Non-Islam, dapat membuat perjanjian perkawinan yang bentuknya harus berupa akta notaris, lalu dapat dicatatkan pada Dinas Kependudukan dan Catatan Sipil.

Bentuk perjanjian perkawinan dalam pemenuhan alat bukti tertulis yang paling kuat dan memberikan kepastian serta perlindungan hukum ialah akta autentik yang dibuat dihadapan Notaris menurut bentuk dan tata cara yang ditetapkan dalam Undang-Undang Nomor 30 Tahun 2004 yang telah diubah dengan Undang-undang Nomor 2 Tahun 2014 tentang tentang Jabatan Notaris (selanjutnya disebut dengan UUJN). Berdasarkan Pasal 22 Permenag RI No. 20/2019 menyebutkan bahwa perjanjian perkawinan dilakukan pada waktu, sebelum dilangsungkan atau selama perkawinan dan harus dibuat dalam suatu akta notaris. Notaris merupakan pejabat umum yang berwenang untuk membuat akta autentik yang menurut bentuk dan tata cara yang ditetapkan dalam UUJN. ${ }^{2}$ Notaris dipandang sebagai bagian dari penguasa yang berperan sebagai kekuasaan negara yang tertuang dalam UUJN yang diaturnya termasuk dalam bidang hukum publik sehingga ketentuan-ketentuan yang terdapat di dalamnya adalah sebagian besar peraturan yang bersifat memaksa (dwingend recht $\left.{ }^{3}\right) .{ }^{4}$ Dasar kewenangan notaris dalam menjalankan tugas dan jawabannya sebagai kekuasaan negara untuk membuat akta autentik dalam hal ini akta perjanjian perkawinan yang telah diatur dalam Pasal 15 UUJN. UUJN menyebut Notaris sebagai pejabat umum yang berwenang untuk membuat akta autentik dan kewenangan lainnya. ${ }^{5}$

Menilik aturan-aturan di atas, bertolak belakang dengan kasus yang terjadi di Jawa Timur. Sepasang suami dan isteri yaitu Tuan Z dan Nyonya R, yang hendak menjual tanah. Untuk menjual tanah, maka mereka menghadap kepada notaris untuk membuat Perjanjian Pengikatan Jual Beli (PPJB). Saat menghadap

\footnotetext{
${ }^{2}$ Tobing Lumban, Peraturan Jabatan Notaris (Erlangga 1983).[29].

${ }^{3}$ Hukum yang bersifat memaksa (dwingend recht) adalah peraturan-peraturan hukum yang tidak boleh dikesampingkan atau disimpangi oleh orang-orang yang berkepentingan, terhadap peraturan-peraturan hukum mana orang-orang yang berkepentingan harus tunduk dan mentaatinya.

${ }^{4}$ Umi Setyawati, Amin Purnawan, 'Akta Penegasan Keterangan Waris Sebagai Pengganti Surat Keterangan Waris Dalam Pengurusan Balik Nama Waris di Kantor Pertanahan Kota Semarang'(2018) 5

${ }^{5}$ Tobing Lumban, Op.Cit.[31].
} Jurnal Akta.[34]. 
kepada Notaris, Notaris mendapati Perjanjian Perkawinan Tuan Z dan Nyonya $\mathrm{R}$ dalam bentuk surat di bawah tangan dan ditegaskan dalam suatu akta dengan judul akta penegasan Perjanjian Perkawinan. Perkawinan antara Tuan Z dan Nyonya R pada tanggal 26 April 2007, sebelum perkawinan berlangsung kedua belah pihak tersebut sepakat untuk membuat suatu perjanjian perkawinan yang dibuat di bawah tangan pada tanggal 1 April 2007. Dalam perjanjian perkawinan Tuan Z dan Nyonya R memuat mengenai hak kepemilikan yang menyatakan bahwa para pihak sepakat untuk membuat perjanjian perkawinan tentang hak kepemilikan harta kekayaan, kepemilikan harta kekayaan sebelum maupun sesudah perkawinan tetap menjadi hak milik masing-masing (harta bawaan dari suami tetap milik suami, harta isteri tetap milik isteri, harta setelah perkawinan atas nama suami tetap milik suami dan harta atas nama isteri tetap milik isteri). Tak hanya mengenai harta kekayaan, namun juga memuat mengenai utang para pihak yang akan menjadi kewajiban oleh masing-masing pihak nantinya. Perjanjian perkawinan tersebut dibuat dalam bentuk di bawah tangan, disaksikan oleh dua orang saksi dengan materai yang cukup, serta mengetahui dan ditandatangani oleh Kepala Desa dan Kepala Kantor Urusan Agama setempat. Kemudian pada tahun 2011 Tuan Z dan Nyonya R menghadap ke Notaris X untuk dibuatkan akta penegasan atas perjanjian perkawinan tersebut. Akta penegasan atas perjanjian perkawinan tersebut didaftarkan pada Register Pengadilan Negeri setempat.

Berdasarkan uraian di atas, terlihat adanya kekosongan hukum dalam peraturan perundang-undangan dalam pembuatan akta penegasan pada pembuatan perjanjian perkawinan di bawah tangan yang berkaitan dengan prinsip publisitas yang mengikat pihak ketiga, mengingat dalam kasus di atas perjanjian perkawinan dibuat tahun 2007 maka berdasarkan Pasal 29 UU Perkawinan menegaskan bahwa perjanjian perkawinan disahkan oleh Pegawai pencatat perkawinan, setelah mana isinya berlaku juga terhadap pihak ketiga sepanjang pihak ketiga tersangkut, sehingga penelitian ini menganalisis mengenai akta penegasan perjanjian perkawinan kaitannya dengan pemenuhan prinsip publisitas. 


\section{Metode Penelitian}

Artikel ini menggunakan tipe penelitian Normatif yaitu suatu penelitian yang secara deduktif dimulai dari analisis terhadap pasal-Pasal dalam peraturan perundang-undang yang mengatur terhadap permasalahan di atas. Pendekatan yang digunakan adalah dengan menggunakan pendekatan Perundang-Undangan (Statute Approach) dan pendekatan konsep (Conceptual Approach). Suatu penelitian normatif tentu harus menggunakan pendekatan perundang-undangan, karena yang akan diteliti adalah berbagai aturan hukum yang menjadi fokus sekaligus tema sentral suatu penelitian. Bahan hukum yang digunakan dalam penelitian hukum normatif ini adalah bahan hukum primer berupa peraturan perundangundangan dan bahan hukum sekunder berupa semua publikasi tentang hukum meliputi buku-buku teks, kamus-kamus hukum, jurnal-jurnal hukum, dan komentar-komentar atas putusan pengadilan.

\section{Prinsip Publisitas Dalam Akta Penegasan Perjanjian Perkawinan Berdasarkan Undang-Undang Nomor 1 Tahun 1974 Tentang Perkawinan}

Perkawinan merupakan Pasal 1 UU Perkawinan menyebutkan bahwa Perkawinan adalah ikatan lahir batin antara seorang laki-laki dan seorang perempuan sebagai pasangan suami dan isteri dengan tujuan membentuk rumah tangga yang bahagia dan berdasarkan Ketuhanan Yang Maha Esa. Perkawinan telah menjadi persoalan yang selalu aktual dan menarik untuk dibicarakan, karena perkawinan merupakan salah satu proses kehidupan yang sangat penting di dalam kehidupan manusia, yang tentunya akan membawa konsekuensi hukum. Sebagian besar pengaruh hukum perkawinan merupakan tentang kebiasaan kepercayaan agama meskipun banyaknya yurisdiksi. ${ }^{6}$

Agar dapat melindungi calon suami dan isteri dari konflik yang mungkin dikemudian hari akan terjadi dalam perkawinannya maka para

${ }^{6}$ Oscar I Roos dan Anita Mackay, 'The Evolutionary Interpretation of Treaties And The Right To Marry: Why Article 23 (2) Of The ICCPR Should Be Reinterpreted To Encompass Same-Sex Marriage' (2017) 49 Journal ICCPR.[895]. 
pihak tersebut dapat membuat perjanjian perkawinan yang mengatur bahwa tidak terbentuk harta Bersama dalam perkawinan atau mereka bersepakat untuk menyatukan harta bawaan mereka masing-masing dalam harta Bersama mereka. Dengan adanya, Putusan Mahkamah Konstitusi Nomor 69/PUUXIII/2015 maka Perjanjian perkawinan, yaitu persetujuan yang dibuat oleh kedua calon mempelai pada waktu, sebelum dilangsungkan atau selama dalam ikatan perkawinan dan masing-masing berjanji akan mentaati apa yang tersebut dalam perjanjian itu, perjanjian perkawinan tersebut dilakukan dihadapan Notaris, yaitu pembuatan perjanjian perkawinan dengan akta notariil, setelah mana isinya berlaku juga terhadap pihak ketiga sepanjang pihak ketiga tersangkut. Perjanjian perkawinan (huwelijks atau huwelijkse voorwaarden) adalah perjanjian yang dibuat oleh dua orang calon suami isteri untuk mengatur akibat-akibat perkawinan yang menyangkut harta kekayaan. ${ }^{7}$ Selain itu pengertian perjanjian perkawinan dapat juga diartikan bahwa suatu perjanjian (persetujuan) yang dibuat oleh calon suami isteri, sebelum atau pada saat perkawinan dilangsungkan untuk mengatur akibat-akibat perkawinan terhadap harta kekayaan mereka, serta juga memuat hal-hal yang berkenaan dengan kepentingan masa depan rumah tangga mereka. Dalam perjanjian perkawinan yang dimana isinya mengenai harta terhadap suami isteri dalam perkawinan dengan harta terpisah tujuannya: ${ }^{8}$

a. Agar barang-barang tertentu atau semua barang yang di bawah suami atau isteri dalam perkawinan tidak termasuk dalam persatuan harta perkawinan dan dengan demikian, tetap menjadi harta pribadi-pribadi. Adanya perjanjian yang demikian merupakan perlindungan bagi isteri, kemungkinan dipertanggung jawabkannya harta tersebut, terhadap hutang-hutang yang dibuat suami maupun sebaliknya.

b. Agar harta pribadi tersebut terlepas dari beheer suami dan isteri dapat

\footnotetext{
${ }^{7}$ ibid.[94].

${ }^{8}$ Christian Supandi, 'Pembagian Harta Bersama Akibat Perceraian Menurut Undang-Undang Nomor 1 Tahun 1974' (2019) 3 Jurnal Lex Privatum.[18].
} 
mengurus sendiri harta tersebut.

Dalam hal ini suatu keabsahan dan keberlakuan perjanjian perkawinan harus memenuhi empat syarat sahnya perjanjian berdasarkan Pasal 1320 BW yaitu: Kesepakatan mereka yang mengikatkan dirinya; Kecakapan untuk membuat suatu perikatan; Suatu hal tertentu; dan Suatu sebab yang tidak terlarang atau diperbolehkan. Mengenai Kecakapan untuk membuat suatu perikatan, Pasal 1329 BW menyebutkan bahwa setiap orang adalah cakap. Pasal 1330 BW memberikan pengecualian dengan penjelasan ada beberapa orang yang tidak cakap untuk membuat perjanjian, yaitu:

a. Orang yang belum dewasa. Berdasarkan Pasal 47 Jo. 50 UU Perkawinan, belum dewasa adalah anak yang belum mencapai umur 18 tahun atau belum pernah melangsungkan perkawinan ada di bawah kekuasaan orang tua atau wali. Begitupun juga dalam hal pembuatan perjanjian perkawinan, bilamana calon pasangan suami isteri sudah berusia 18 tahun maka mereka sudah cakap untuk membuat perjanjian perkawinan, akan tetapi jika calon pasangan suami isteri belum mencapai usia 18 tahun atau belum pernah melangsungkan perkawinan maka calon pasangan tersebut harus diwakili atau sekurang-kurangnya didampingi oleh orang tuanya atau walinya.

b. Orang yang ditaruh di bawah pengampuan (curatele atau conservatorship). Seseorang dapat diletakan di bawah pengampuan apabila yang bersangkutan gila, dungu (onnoozelheid), mata gelap (razernij), lemah akal (zwakheid van vermogens), ataupun pemboros. Orang yang demikian itu tidak menggunakan akal sehatnya, dan oleh karenanya dapat merugikan dirinya sendiri. Selain itu, seseorang yang mengalami kepailitan menjadi tidak cakap untuk melakukan perikatan tertentu sejak pernyataan pailit diucapkan oleh Pengadilan.

c. Orang-orang perempuandalampernikahan, namunsetelah diterbitkannyaSurat Edaran Mahkamah Agung No. 3 tahun 1963 dan diundangkannya UU Perkawinan Pasal 31 ayat (2) maka perempuan dalam perkawinan dianggap cakap hukum. 
Peraturan perundang-undangan yang mengatur terkait batasan umur seseorang untuk melaksanakan perkawinan adalah UU Perkawinan Jo. Undang-Undang Nomor 16 Tahun 2019 Tentang Perubahan Atas UndangUndang Nomor 1 Tahun 1974 tentang Perkawinan dan Peraturan Pemerintah Republik Indonesia Nomor 9 Tahun 1975 Tentang Pelaksanaan Undang-Undang Nomor 1 Tahun 1974 Tentang Perkawinan (PP No. 9/1975). Berdasarkan Pasal 7 Undang-Undang Nomor 16 Tahun 2019 Tentang Perubahan Atas UndangUndang Nomor 1 Tahun 1974 tentang Perkawinan maka yang dimaksud batasan usia kawin adalah usia 19 tahun bagi laki-laki dan bagi perempuan. Tujuan dari ditetapkannya batasan umur ini adalah untuk menjaga kesehatan suamiisteri dan keturunan. Apabila tetap ingin melaksanakan perkawinan jika umur salah satu atau kedua calon mempelainya di bawah ketentuan maka dapat melaksanakan hal tersebut dengan cara, kedua orang tua laki-laki maupun kedua orang tua perempuan dapat meminta dispensasi atas ketentuan umur kepada Pengadilan Agama bagi yang beragama Islam dan Pengadilan Negeri bagi yang non-Islam (Pasal 7 ayat (2) UUP Jo. Pasal 1 huruf b PP No. 9/1975). Pengajuan dispensasi tersebut diajukan ke Pengadilan sesuai wilayah tempat tinggal pemohon.

Keabsahan Perjanjian Perkawinan adalah salah satu perbuatan hukum, oleh sebab itu akibat hukum dari perjanjian perkawinan sangat erat kaitannya dengan sahnya perjanjian perkawinan itu sendiri. Suatu Perjanjian perkawinan dianggap sah apabila telah memenuhi Pasal 22 Permenag RI No. 20/2019 dan berdasarkan pada Surat Edaran 472.2/5876/Dukcapil Tentang Pencatatan Pelaporan Perjanjian Perkawinan. Maka dapat digambarkan pada tabel di bawah ini tentang perbandingan perjanjian perkawinan menurut BW, UU Perkawinan, Permenag RI No. 20/2019 dan Surat Edaran 472.2/5876/Dukcapil Tentang Pencatatan Pelaporan Perjanjian Perkawinan. 
Tabel 1. Perjanjian Perkawinan menurut BW, UU Perkawinan, Permenag RI No. 20/2019 dan Surat Edaran 472.2/5876/Dukcapil

\begin{tabular}{|c|c|c|c|}
\hline Ket & BW & UU Perkawinan & $\begin{array}{c}\text { Permenag RI No. 20/2019 } \\
\text { dan Surat Edaran } \\
\text { 472.2/5876/Dukcapil }\end{array}$ \\
\hline Bentuk & $\begin{array}{l}\text { Bentuk akta } \\
\text { autentik } \\
\text { (Pasal 147 BW) }\end{array}$ & $\begin{array}{l}\text { Bentuk tertulis } \\
\text { (Pasal } 29 \text { ayat (1) UU } \\
\text { Perkawinan) }\end{array}$ & $\begin{array}{l}\text { Akta Notariil } \\
\text { (Pasal } 22 \text { Permenag RI } \\
\text { No. 20/2019) }\end{array}$ \\
\hline Waktu & $\begin{array}{l}\text { Sebelum per- } \\
\text { kawinan }\end{array}$ & $\begin{array}{l}\text { Pada waktu atau sebe- } \\
\text { lum perkawinan }\end{array}$ & $\begin{array}{l}\text { pada waktu, sebelum dil- } \\
\text { angsungkan atau selama } \\
\text { dalam ikatan }\end{array}$ \\
\hline Isi Perjanjian & $\begin{array}{l}\text { Isi perjanjian per- } \\
\text { kawinan tidak } \\
\text { boleh melanggar } \\
\text { tata susila yang } \\
\text { baik atau tata ter- } \\
\text { tib umum }\end{array}$ & $\begin{array}{l}\text { Isi perjanjian perjawinan } \\
\text { tidak boleh bertentan- } \\
\text { gan dengan hukum, ag- } \\
\text { ama dan kesusilaan }\end{array}$ & $\begin{array}{l}\text { Isi perjanjian tidak boleh } \\
\text { bertentangan dengan } \\
\text { hukum Islam dan/atau } \\
\text { ketentuan peraturan pe- } \\
\text { rundangundangan }\end{array}$ \\
\hline Keabsahan & $\begin{array}{l}\text { Perjanjian kaw- } \\
\text { in harus dibuat } \\
\text { dengan akta no- } \\
\text { taris sebelum } \\
\text { pernikahan ber- } \\
\text { langsung }\end{array}$ & $\begin{array}{l}\text { Disahkan oleh pegawai } \\
\text { pencatatan perkawinan }\end{array}$ & $\begin{array}{l}\text { Dicatatkan perjanjian } \\
\text { perkawinan oleh Kepala } \\
\text { KUA Kecamatan/PPN } \\
\text { LN pada akta nikah dan } \\
\text { buku nikah }\end{array}$ \\
\hline Perubahan & $\begin{array}{l}\text { Tidak dapat diu- } \\
\text { bah }\end{array}$ & $\begin{array}{l}\text { Tidak dapat diubah } \\
\text { atau dicabut, kecuali } \\
\text { bila dari kedua belah } \\
\text { pihak ada persetujuan } \\
\text { untuk mengubah } \\
\text { atau mencabut dan } \\
\text { perubahan } \\
\text { pencabutan itu tidak } \\
\text { merugikan pihak ketiga }\end{array}$ & $\begin{array}{l}\text { Tidak dapat diubah atau } \\
\text { dicabut, kecuali bila dari } \\
\text { kedua belah pihak ada } \\
\text { persetujuan untuk men- } \\
\text { gubah atau mencabut dan } \\
\text { perubahan atau pencabu- } \\
\text { tan itu tidak merugikan } \\
\text { pihak ketiga. Perubahan } \\
\text { dan pencabutan harus di- } \\
\text { laporkan }\end{array}$ \\
\hline Pengaturan & $\begin{array}{l}\text { Diatur dalam } \\
\text { Pasal } 139 \text { BW } \\
\text { sampai dengan } \\
\text { Pasal 154 BW } \\
\end{array}$ & Pasal 29 UU Perkawinan & $\begin{array}{l}\text { Pasal } 22 \text { dan Pasal } 23 \text { Per- } \\
\text { menag RI No. 20/2019 }\end{array}$ \\
\hline
\end{tabular}

Ada lima unsur penting dalam Pasal 29 ayat (1) UU Perkawinan Jo. Permenag RI No. 20/2019 Jo. Surat Edaran 472.2/5876/Dukcapil, unsur penting tersebut dapat dijadikan acuan syarat sahnya perjanjian perkawinan, yaitu: (1) perjanjian dibuat sebelum, pada saat dan selama masa perkawinan; (2) persetujuan bersama;

(3) dibuat secara tertulis; (4) disahkan oleh pegawai pencatat perkawinan ; dan

(5) berlaku terhadap pihak ketiga sepanjang pihak ketiga tersangkut. 
Menurut penuturan Direktur Jenderal Kependudukan dan Pencatatan Sipil Kementerian Dalam Negeri (Dirjen Dukcapil Kemendagri) Zudan Arif Fakrulloh, bahwa ada dua syarat agar perjanjian perkawinan dapat dicatat di Dukcapil, ${ }^{9}$ yaitu yang Pertama, perjanjian perkawinan itu harus berupa akta notariil, hal ini telah diatur dalam Surat Edaran 472.2/5876/Dukcapil Tentang Pencatatan Pelaporan Perjanjian Perkawinan. Dimaksud sebagai akta notariil adalah akta yang dibuat dan dibacakan serta ditandatangani di depan Notaris. Petugas Dinas Dukcapil tidak menerima Perjanjian Perkawinan yang tidak berupa akta notariil. Lalu yang Kedua, perjanjian perkawinan dicatat di Dukcapil apabila memang perkawinan tersebut sudah tercatat melalui hukum negara Indonesia. Perjanjian perkawinan tidak dapat dilaksanakan apabila suatu perkawinan itu adalah perkawinan siri atauu tidak dicatatkan di Kantor Urusan Agama.

Dalam UU Perkawinan dan Putusan MK No. 69/PUU-XII/2015, bentuk Perjanjian Perkawinan dalam bentuk perjanjian tertulis yang disahkan oleh pegawai pencatat perkawinan setelah mana isinya berlaku juga terhadap pihak ketiga sepanjang pihak ketiga tersangkut. Dapat ditafsirkan bahwa bentuk perjanjian perkawinan yang dibuat secara tertulis tersebut dapat dalam bentuk perjanjian di bawah tangan atau dengan akta Notaris. Perjanjian di bawah tangan tidak memiliki nilai pembuktian yang sempurna, karena saat salah satu pihak mengingkari isi perjanjian, pihak lainnya akan kesulitan untuk membuktikannya. Dalam hal pembuktian perjanjian di bawah tangan, hanya mempunyai kekuatan pembuktian formal, yaitu bila tanda tangan serta pernyataan yang tercantum dalam surat tersebut itu diakui dan dibenarkan maka perjanjian di bawah tangan itu sebenarnya sudah memiliki kekuatan dalam pembuktian. Secara materiil, kekuatan pembuktian perjanjian di bawah tangan tersebut hanya berlaku terhadap orang yang diberikan pernyataan, sedangkan hakim memberikan penilaian atau

${ }^{9}$ KlikLegal.Com, 'Ini Dua Syarat Agar Perjanjian Perkawinan Bisa Dicatat Di Dukcapil' (KlikLegal.Com, 2017) <https:/ / kliklegal.com/ini-dua-syarat-agar-perjanjian-perkawinan-bisa-dicatatdi-dukcapil/>. 
pembuktian bebas terhadap pihak lain. ${ }^{10}$ Sedangkan Akta Notariil yang biasa disebut dengan akta autentik, autentik itu berarti sah, harus dibuat dihadapan pejabat yang berwenang. Oleh karena itu, Notaris adalah pejabat umum yang berwenang dalam proses pembuatan akta, maka akta yang dibuat dihadapan atau oleh notaris merupakan akta autentik, atau akta itu sah. Selain itu akta autentik adalah akta yang memiliki pembuktian yang sempurna

Bentuk perjanjian perkawinan bagi yang beragama Islam diatur dalam Pasal 22 ayat (2) Permenag RI No. 20/2019, yang menyebutkan bahwa perjanjian perkawinan sebagaimana dimaksud pada ayat (1) dilakukan dihadapan notaris, yang dimaksud dihadapan notaris yaitu terdapat dalam Pasal 1 angka 7 UUJN yang menyebutkan bahwa "Akta Notaris yang selanjutnya disebut Akta adalah akta autentik yang dibuat oleh atau di hadapan Notaris menurut bentuk dan tata cara yang ditetapkan dalam Undang-Undang ini". Maka yang dimaksud perjanjian perkawinan dilakukan dihadapan notaris adalah perjanjian perkawinan dibuat dalam bentuk akta notaris. Bentuk Perjanjian perkawinan bagi yang beragama non-Islam diatur dalam Surat Edaran 472.2/5876/Dukcapil Tentang Pencatatan Pelaporan Perjanjian Perkawinan, Surat Edaran tersebut menidaklanjuti Putusan MK No. 69/PUU-XII/2015 yang menyebutkan bahwa Perjanjian perkawinan dibuat dalam bentuk akta Notaris, hal ini tercantum dalam point kesatu dalam surat edaran tersebut. Adanya Surat Edaran 472.2/5876/Dukcapil Tentang Pencatatan Pelaporan Perjanjian Perkawinan, surat tersebut untuk menindaklanjuti terkait adanya Putusan MK No. 69/PUU-XII/2015. Namun, untuk melakukan usaha menafsirkan Putusan MK No. 69/PUU-XII/2015 oleh Ditjen Dukcapil tidak sesuai dengan amar putusan yang telah disebutkan oleh MK. Pada point pertama disebutkan bahwa perjanjian perkawinan dibuat dengan akta Notaris, sedangkan MK dalam amar putusannya hanya menyebutkan bahwa perjanjian perkawinan dapat dibuat secara tertulis yang berarti dapat dibuat di bawah tangan maupun dengan akta Notaris.

10 Yudha Tri Dharma Iswara, I Ketut Markeling, 'Kekuatan Pembuktian Surat Di Bawah Tangan Dalam Akta Perjanjian Jual-Beli' (2016) 4 Journal Ilmu Hukum Kertha Semaya.[8]. 
Mengenai kewenangan Notaris dalam pembuatan perjanjian perkawinan ini, supaya dapat melindungi pihak ketiga. Apabila pihak suami dan isteri membuat perjanjian perkawinan di bawah tangan, lalu terjadi konflik dengan pihak ketiga, bisa saja suami dan isteri tersebut mengubah dengan mudahnya perjanjian perkawinan tersebut. Berbeda halnya apabila pembuatan perjanjian perkawinan dengan akta notariil, dengan dibuatnya dengan akta notariil, akta minuta perjanjian perkawinan akan disimpan oleh notaris, maka tidak dapat dengan mudahnya suami dan isteri mengubah isi perjanjian perkawinan.

Makna Akta Penegasan Perjanjian Perkawinan, dalam implementasinya pada peraturan perundang-undangan terdapat suatu perbuatan hukum setelah akta notaris dibuat harus dilaporkan atau diberitahukan kepada instansi yang bersangkutan ataupun untuk memperoleh pengesahan atau pendaftaran, karena dengan alasan tertentu jika hal tersebut menjadi kewajiban Notaris, ternyata lupa untuk melaporkan atau memberitahukan atau mendaftarkannya, Notaris dapat membuat akta penegasan yang di dalam akta tersebut sekaligus menerangkan adanya kesalahan redaksi dan alasan dibuatnya akta penegasan. ${ }^{11}$ Fungsi dari Akta Penegasan itu sendiri apabila terjadinya suatu keterlambatan dalam mengajukan permohonan pengesahan, pendaftaran, pelaporan atau pemberitahuan (sepanjang tidak ditentukan lain dalam peraturan perundang-undangan yang bersangkutan), atau akibat hukumnya tidak dicantumkan dalam Pasal-Pasal yang bersangkutan, maka hal tersebut dapat dibuat Akta Penegasan. Bahwa yang dimaksud dengan Akta Penegasan tersebut, bukan (keberadaan) aktanya yang ditegaskan, tapi perbuatan atau tindakkan para penghadap yang tersebut atau tercantum dalam akta tersebut ditegaskan kembali oleh para penghadap. Namun, yang menegaskan bukan Notaris, tetapi para penghadap sendiri di hadapan Notaris. Notaris dalam pembuatan akta Penegasan tersebut harus memperhatikan: (1) bahwa antara sejak tanggal akta dibuat sampai dibuat akta penegasan, jika terjadi tindakkan hukum yang merugikan atau menguntungkan para penghadap (atau pihak lain) menjadi

\footnotetext{
${ }^{11}$ Amalia, 'Peran Notaris Dalam Proses Perubahan Anggaran Dasar Perseroan Terbatas' (Universitas Indonesia 2009).[67].
} 
tanggung jawab penghadap sepenuhnya; (2) dalam Premis tidak menyebutkan alasan dibuatnya akta Penegasan tersebut, kecuali para penghadap sendiri yang meminta/ menginginkannya; (3) dalam Premis tidak perlu diuraikan alasan keterlambatan tersebut, jika keterlambatan tersebut karena kelalaian Notaris sendiri, dan jika dapat dibuktikan maka Notaris dapat dituntut ganti rugi oleh para penghadap; (4) jika ingin masuk ke sistem (secara daring), maka nomor dan tanggal/bulan/tahun akta penegasan tersebut yang didaftarkan. Akta penegasan biasanya dapat ditemui dalam proses perubahan anggaran dasar perseroan terbatas, pendaftaran Yayasan dan lain sebagainya.

Dalam hal kewenangan Notaris membuat akta penegasan pun tidak dapat ditemukan dalam peraturan perundang-undang manapun. Dalam UUJN tidak mengatur bahwa notaris berwenang membuat suatu akta penegasan atau penegasan perbuatan hukum. Keberadaan akta penegasan sendiri hanya ada dalam praktik keterlambatan pendaftaran suatu perbuatan hukum saja. Salah satu alasan terjadinya pembuatan akta penegasan yaitu terjadinya kekosongan hukum karena pada praktiknya akta penegasan ini sering digunakan apabila terjadi suatu keterlambatan pendaftaran perbuatan hukum disamping itu terjadinya pembuatan akta penegasan ini juga suatu kebutuhan masyarakat, namun dalam peraturan perundang-undangan di Indonesia tidak ada hal yang mengatur mengenai akta penegasan itu sendiri. Hal tersebut tidak dapat dianalogikan dengan akta penegasan pada kasus dalam penelitian ini. Dalam kasus penelitian ini akta penegasan dibuat berdasarkan perjanjian perkawinan di bawah tangan yang pada waktu itu tidak dilakukan pendaftaran ke pegawai pencatatan perkawinan sebagaimana ditentukan pada Pasal 29 UU Perkawinan maka perjanjian perkawinan tersebut tidak sah dan tidak mengikat pihak ketiga.

Bilamana mengacu pada Permenag RI No. 20/2019 dan Surat Edaran 472.2/5876/Dukcapil dijelaskan bahwa perjanjian perkawinan harus dibuat oleh notaris dan dilakukan pencatatan. Dengan dibuatkannya akta penegasan perjanjian perkawinan oleh notaris tidak merubah kekuatan perjanjian perkawinan di bawah tangan. Jadi akta penegasan dalam pembuatan perjanjian perkawinan tidak mempunyai akibat hukum terhadap perjanjian perkawinan di bawah tangan 
dikarenakan dalam pembuatan perjanjian perkawinan harus dibuat dalam bentuk akta notaris. Pembuatan akta penegasan perjanjian perkawinan ini juga menyalahi aturan kode etik sebagaimana dalam Pasal 3 angka 1 Kode Etik Notaris. Dalam pembuatan dan pencatatan Perjanjian Perkawinan pasca Putusan MK Nomor 69/ PUU-XIII/2015 dapat dibuat sewaktu-waktu selama masih dalam waktu masa perkawinan. Dalam perjanjian perkawinan tidak mengenal keterlambatan dalam pembuatan perjanjian perkawinan, perjanjian perkawinan dapat dibuat kapanpun selagi masih dalam ikatan perkawinan.

Penerapan prinsip publisitas dalam ranah hukum, dapat dilihat pada prinsip publisitas itu sendiri adalah pemberitahuan atau pengumuman kepada pihak lain atau pihak ketiga berkenaan dengan peristiwa hukum terjadi. Prinsip Publisitas dalam perjanjian perkawinan terdapat dalam Pasal 29 ayat (1) UU Perkawinan Jo. Putusan MK No. 69/PUU-XII/2015, kata “disahkan” adalah bentuk prinsip publisitas perjanjian perkawinan. Perjanjian perkawinan harus didaftarkan, agar dapat memenuhi prinsip publisitas dari perjanjian perkawinan dimaksud. Pendaftaran dan pencatatan perjanjian perkawinan pada buku nikah dan akta nikah adalah untuk memenuhi "prinsip publisitas". ${ }^{12}$ Pengesahan perjanjian perkawinan yang dilakukan oleh Pegawai Pencatat Perkawinan terdapat unsur yaitu, bersifat publikasi kepada pihak ketiga berkaitan dengan keberadaan perjanjian perkawinan tersebut.

Terdapat 2 (dua) istilah dalam pengesahan perjanjian perkawinan, yaitu pendaftaran dan pencatatan. Menurut Moch Isnaeni, pendaftaran yang dimaksud oleh Pasal 29 ayat (1) UU Perkawinan Jo. Putusan MK No. 69/PUU-XII/2015, bukan sebagai syarat untuk menentukan sah tidaknya perjanjian perkawinan, tetapi sekadar pelaporan atau pemindahbukuan adanya sebuah perkawinan yang sudah dilangsungkan. ${ }^{13}$ Istilah yang dipergunakan dalam Pasal 29 ayat (1) UU Perkawinan Jo. Putusan MK No. 69/PUU-XII/2015 adalah didaftarkan

\footnotetext{
${ }^{12}$ Trisadini Prasastinah Usanti dan Ghansham Anand, Hukum Keluarga dan Hukum Perkawinan (Revka Prima Media 2019).[117].

${ }^{13}$ Moch. Isnaeni, Hukum Perkawinan Indonesia (Refika Aditama 2016).[142].
} 
yang hampir sama dengan istilah yang dipergunakan dalam Permenag RI No. 20/2019 dan Surat Edaran 472.2/5876/Dukcapil yang menggunakan kata dicatat. Sebenarnya baik istilah didaftar maupun dicatat adalah menyangkut urusan administrasi yang diperlukan agar pihak ketiga mengetahui dan tunduk pada aturan dalam perjanjian perkawinan yang telah dibuat oleh pasangan kawin tersebut. dengan secara tertulis dalam register umum.

Fungsi pencatatan dalam register umum adalah untuk memenuhi prinsip publisitas yaitu agar adanya Perjanjian perkawinan diketahui oleh pihak ketiga sehingga dapat diberlakukan terhadap pihak ketiga terkait. ${ }^{14}$ Agar dapat memenuhi prinsip publisitas perjanjian perkawinan wajib disahkan oleh Pegawai Pencatat Perkawinan pada instansi yang telah ditentukan. Urgensi pengesahan ini, agar pihak ketiga mengetahui dan tunduk pada perjanjian perkawinan tersebut, seperti apabila terjadinya jual-beli oleh suami atau isteri, jika ada perjanjian perkawinan maka perjanjian perkawinan tersebut akan mengikatnya dalam tindakan hukum yang akan dilakukannya. Pengesahan yang dilakukan oleh pegawai pencatat perkawinan hanya untuk mencatatkan perjanjian perkawinan tersebut yang nantinya perjanjian perkawinan termuat di dalam akta perkawinan. Sehingga, pihak ketiga yang terkait akan mengetahui tentang adanya perjanjian perkawinan tersebut. ${ }^{15}$ Jika tidak didaftarkan, maka perjanjian perkawinan hanya mengikat/berlaku bagi para pihak yang membuatnya, yakni suami dan isteri yang bersangkutan. Hal ini sesuai dengan Pasal 1313, 1315 dan 1340 BW, dimana perjanjian hanya mengikat bagi para pihak yang membuatnya.

\section{Akibat Hukum Yang Timbul Dari Akta Penegasan Perjanjian Perkawinan Terhadap Harta Kekayaan Suami Isteri}

Berdasarkan Kamus Besar Bahasa Indonesia, Harta merupakan barang yang dapat berupa Uang dan sebagainya yang menjadi kekayaan. Dalam Kamus Besar

\footnotetext{
${ }^{14}$ Sylvia Widjaja, 'Aneka Permasalahan Mengenai Perjanjian Kawin Pengesahan atau Pencatatan' (2015) 7 Jurnal Dialogia Iuridica.[88].

${ }^{15}$ Erdhyan Paramita, Irnawan Darori, 'Akibat Hukum Perjanjian Perkawinan Yang Tidak Disahkan Oleh Pegawai Pencatat Perkawinan' (2017) 4 Jurnal Repertorium.[36].
} 
Bahasa Indonesia, istilah yang digunakan adalah gana-gini, yang secara hukum artinya "Harta yang berhasil dikumpulkan selama rumah tangga sehingga 2 (dua) menjadi hak berdua suami dan isteri. ${ }^{16}$ Hal yang dimaksud dengan harta benda perkawinan adalah semua harta yang dikuasai suami isteri selama mereka terikat dalam suatu ikatan perkawinan, baik harta kerabat yang dikuasai, maupun harta perorangan yang berasal dari harta warisan, harta penghasilan sendiri, harta hibah, harta pencarian bersama suami isteri dan barang-barang hadiah, sedangkan harta menurut istilah yaitu segala sesuatu yang dimanfaatkan pada sesuatu yang legal menurut hukum syara' seperti jual beli, pinjam meminjam, konsumsi dan hibah atau pemberian yang bermanfaat bagi semua manusia.

Harta Benda perkawinan diatur dalam UU Perkawinan Pasal 35 sampai dengan Pasal 37, Jika seorang pria dan seorang wanita kawin maka dapat menimbulkan akibat hukum karena kawin adalah suatu perbuatan hukum. Akibat hukumnya yaitu, pria menjadi suami, wanita menjadi isteri, selain itu akibat hukumnya tidak hanya bagi mereka tetapi juga terhadap harta mereka. Diketahui bahwa harta bawaan adalah harta yang dibawa masing-masing baik dari pihak suami maupun pihak isteri yang berupa hadiah, atau warisan, atau segala harta benda yang di bawah penguasaan masing-masing sepanjang para pihak tidak menentukan lain. Harta bawaan merupakan harta yang dibawa oleh masingmasing suami ataupun isteri sebelum adanya perkawinan. Seperti, Seorang wanita yang pada saat akan melangsungkan perkawinan telah bekerja di perusahaan selama 5 (lima) tahun dan dari hasil kerjanya itu ia dapat membeli rumah, maka ketika terjadinya perkawinan, rumah tersebut merupakan harta bawaan isteri. Menurut UU Perkawinan, harta bawaan tersebut berada di bawah penguasaan masing-masing suami dan isteri. Masing-masing suami dan isteri memiliki hak sepenuhnya untuk melakukan perbuatan hukum mengenai harta bawaannya. Namun meski demikian, UU Perkawinan juga memberikan kesempatan kepada suami isteri untuk menentukan lain, yaitu melepaskan hak atas harta bawaan

${ }^{16}$ Kamus Besar Bahasa Indonesia (Balai Pustaka 2001).[330]. 
tersebut dari penguasaannya masing-masing (dipersatukan menjadi harta bersama). Pengecualian ini harus ditentukan dengan perjanjian perkawinan.

Tentang harta bersama ini, suami atau isteri dapat bertindak untuk berbuat sesuatu atas harta bersama itu atas persetujuan kedua belah pihak. Dinyatakan pula bahwa suami atau isteri mempunyai hak sepenuhnya untuk melakukan perbuatan hukum mengenai harta bersama tersebut apabila perkawinan putus karena perceraian, maka harta bersama tersebut diatur menurut hukum masing-masing. ${ }^{17}$ Agar memperjelas pengertian di atas, hal-hal di bawah ini perlu menjadi catatan: ${ }^{18}$

a. Benda-benda yang dibeli dari harta suami, seperti meja, ranjang tidur, kompor, motor, mobil adalah hak suami dan bukan merupakan harta harta bersama, termasuk dalam hal ini adalah harta warisan yang didapatkan suami atau hadiah dari orang lain yang diberikan secara khusus kepada suami;

b. Benda-benda yang dibeli dari harta suami, kemudian secara nyata dan jelas telah diberikan kepada isterinya, misalnya suami yang membelikan mobil dan perhiasan kepada isterinya, atau suami membelikan sepeda dan dihadiahkan kepada isterinya, maka terhadap harta tersebut walaupun dibeli dengan harta suami, tetapi telah menjadi hak milik isteri, dan bukan pula termasuk dalam harta bersama;

c. Benda-benda yang dibeli dari harta isteri atau orang lain yang menghibahkan sesuatu khusus kepada isteri, maka itu semua adalah menjadi hak isteri dan bukan termasuk harta harta bersama.

Harta bersama tersebut berada di dalam kekuasaan suami dan isteri secara bersama-sama, sehingga harta bersama adalah harta benda yang diperoleh selama perkawinan, yang mana harta benda ini bersangkutan dengan perbuatan hukum yang salah satunya seperti menjaminkan atau menjual baik yang dilakukan dari salah satu pihak yaitu suami atau isteri sehingga diperlukan adanya persetujuan

${ }^{17}$ Evi Djuniarti, 'Hukum Harta Bersama Ditinjau Dari Perspektif Undang-Undang Perkawinan Dan KUH Perdata’ (2017) 17 Jurnal Penelitian Hukum De Jure.[ 448]. Islam.[83].

${ }^{18}$ Liky Faizal, 'Harta Bersama Dalam Perkawinan' (2015) 8 Jurnal Pengembangan Masyarakat 
dari lawan kawinnya (spouse letter) $\cdot{ }^{19}$ Jadi pada prinsipnya harta bersama tersebut diatur dan digunakan bersama dan dalam segala halnya harus ada persetujuan bersama tetapi dalam hal persetujuan bersama bukanlah menjadi suatu syarat mutlak karena dapat membawa suatu kesulitan bagi kehidupan berumah tangga. ${ }^{20}$ Makna dari kalimat sepanjang para pihak tidak menentukan menunjukkan bahwa ketentuan harta benda perkawinan dalam UU Perkawinan bersifat mengatur (regelend recht). Para Pihak atas dasar sepakat dapat mengesampingkan prinsip yang berlaku dalam harta benda perkawinan dengan membuat aturan tersendiri dengan membuat perjanjian perkawinan sebagaimana diatur pada Pasal 29 UU Perkawinan. Prinsip yang dianut dalam Pasal 36 UU Perkawinan adalah pola terpisah (pemisahan harta perkawinan), hal ini dibuktikan dengan adanya harta bawaan dan harta bersama. Pola seperti ini dikenal dalam hukum adat sehingga ada harta gono gini. ${ }^{21}$ Dalam hukum adat, harta benda dalam perkawinan disebut dengan Harta gono-gini adalah harta benda dalam perkawinan yang didapatkan oleh pasangan suami isteri secara bersama-sama selama masa perkawinan masih berlangsung. Istilah gono-gini merupakan sebuah istilah hukum yang populer di masyarakat.

Adapun kasus yang menjadi penelitian ini, yang bermula dari Tuan $\mathrm{Z}$ dan Nyonya R membuat perjanjian pasca perkawinan dalam bentuk perjanjian di bawah tangan pada tahun 2007 yang kemudian dibuatkan akta penegasan atas perjanjian perkawinannya oleh Notaris X pada tahun 2011. Berdasarkan kasus tersebut, perjanjian perkawinan dalam bentuk di bawah tangan merupakan perjanjian perkawinan yang sengaja dibuat oleh para pihak sendiri tanpa melalui pejabat umum yang mempunyai kewenangan membuat akta. Kekuatan pembuktian dari perjanjian di bawah tangan dapat dikatakan masih diragukan serta dapat dibantahkan karena kekuatan pembuktian dari perjanjian di bawah

\footnotetext{
${ }^{19}$ Moch. Isnaeni, Op.Cit.[80].

${ }^{20}$ Ratna D. E. Sirait, 'Kedudukan Harta Dalam Perkawinan Campuran Ditinjau Dari UndangUndang No. 1 Tahun 1974' <http://www.ust.ac.id/assets/file/penelitian/ratna-d-e-sirait-sh-mhum_1551070153.pdf>.diakses pada 19 Nopember 2020.

${ }^{21}$ Trisadini Prasasinah Usanti, Ghansham Anand, Op.Cit.[84].
} 
tangan hanya dapat dibuktian dari pengakuan para pihak yang membuatnya serta turut menandatangi perjanjian tersebut. Dengan demikian, kekuatan pembuktian perjanjian di bawah tangan dianggap tidak kuat dan masih dibutuhkannya itikad baik (good faith) dari para pihak. Terhadap adanya suatu alat bukti dalam bentuk perjanjian di bawah tangan yang hanya memiliki kekuatan pembuktian secara formal, yaitu apabila tanda tangan yang ada pada perjanjian itu diakui (termasuk suatu bukti pengakuan), yang merupakan suatu pernyataan yang tercantum dalam akta itu diakui dan dibenarkan pula. Namun, secara materilnya, kekuatan pembuktian perjanjian di bawah tangan hanya berlaku terhadap orang untuk siapa pernyataan itu diberikan, sedangkan terhadap pihak lain, kekuatan pembuktiannya tergantung pada penilaian hakim (pembuktian bebas). Semua perkara di persidangan adalah semata-mata termasuk kekuasaan atau wewenang hakim atau pengadilan untuk memutuskannya. Hakim atau pengadilan ini merupakan alat perlengkapan dalam suatu negara hukum yang ditugaskan menetapkan hubungan hukum yang sebenarnya antara dua pihak yang terlibat dalam perselisihan atau persengketaan. ${ }^{22}$ Apabila dalam persidangan yang diajukan sebagai bukti hanyalah suatu perjanjian di bawah tangan mengingat kekuatan pembuktiannya yang terbatas, sehingga masih diupayakan alat bukti lain yang mendukungnya sehingga diperoleh bukti yang dianggap cukup untuk mencapai kebenaran menurut hukum. Jadi suatu perjanjian di bawah tangan untuk dapat menjadi bukti yang sempurna dari bukti tertulis itu masih harus dilengkapi dengan alat-alat bukti lainnya.

Oleh karena itu, dapat dikatakan bahwa perjanjian di bawah tangan itu merupakan bukti tertulis (begin van schriftelijk bewijs) (Pasal 1871 BW). Sedangkan, kekuatan pembuktian akta autentik, dalam Pasal 1868 BW menyatakan bahwa suatu akta autentik ialah suatu akta yang dibuat dalam bentuk yang ditentukan UU oleh atau dihadapan pejabat umum yang berwenang untuk itu di tempat akta itu dibuat" dan dalam Pasal 1870 dan 1871 BW, Akta autentik adalah alat

\footnotetext{
${ }^{22}$ Meitinah,' Kekuatan Pembuktian Akta Di Bawah Tangan Yang Telah Memperoleh Legalisasi Dari Notaris' (2006) 36 Jurnal Hukum \& Pembangunan.[458].
} 
pembuktian yang sempurna bagi kedua pihak, sekalian orang yang mendapat haknya dari akta tersebut memberikan kepada pihak-pihak suatu pembuktian yang mutlak. Akta Autentik merupakan suatu alat bukti yang sempurna sebagaimana diatur dalam Pasal 1870 BW, akta ini memiliki kekuatan bukti sedemikian rupa karena dianggap melekatnya pada akta itu sendiri sehingga tidak perlu dibuktikan lagi dan bagi hakim, akta ini merupakan bukti wajib (Verplicht Bewijs), dengan demikian barang siapa yang menyatakan bahwa akta autentik itu palsu maka ia harus membuktikan tentang kepalsuan akta itu, oleh karena itulah maka akta autentik memiliki kekuatan pembuktian baik lahiriah, formil maupun materiil. ${ }^{23}$

Perjanjian perkawinan berupa di bawah tangan lalu dibuatkannya akta penegasan perjanjian perkawinan antara Tuan $\mathrm{Z}$ selaku mempelai pria dengan Nyonya R selaku mempelai wanita yang dibuat sebelum perkawinan pada 1 April 2007 mengenai hak kepemilikan harta kekayaan dengan isi perjanjian sebagai berikut: (1) bahwa kepemilikan harta kekayaan sebelum maupun sesudah kami menikah (sebelum menjadi suami isteri) tetap menjadi hak milik masing-masing (harta yang asalnya dari suami tetap milik suami dan harta yang asalnya dari isteri tetap milik isteri, harta setelah perkawinan atas nama suami menjadi hak milik suami dan harta atas nama isteri menjadi hak milik isteri; (2) utang atas nama suami menjadi kewajiban suami dan utang atas nama isteri menjadi kewajiban isteri. Apabila dikaji berdasarkan pada Permenag RI No. 20/2019 dan Surat Edaran 472.2/5876/Dukcapil yang menyebutkan bahwa perjanjian perkawinan dibuat pada waktu, sebelum ataupun selama perkawinan dalam bentuk perjanjian notariil, setelah mana isinya berlaku juga terhadap pihak ketiga sepanjang pihak ketiga terkait, maka perjanjian perkawinan yang dibuat di bawah tangan yang dibuat oleh para pihak tersebut tidak sesuai dengan Permenag RI No. 20/2019 dan Surat Edaran 472.2/5876/Dukcapil. Perjanjian perkawinan yang dibuat dengan

${ }^{23}$ I Ketut Tjukup, I Wayan Bela Siki Layang, Nyoman A. Martana, I Ketut Markeling, Nyoman Satyayudha Dananjaya, I Putu Rasmadi Arsha Putra, Komang Widiana Purnawan, Made Diah Sekar Mayang Sari, Ketut Nihan Pundari dan Putu Ayu Ratih Tribuana, 'Akta Notaris (Akta Otentik) Sebagai Alat Bukti Dalam Peristiwa Hukum Perdata' (2016) 1 Jurnal Ilmiah Prodi Magister Kenotariatan.[185]. 
akta notaris kemudian ditandatangani oleh para pihak. Dengan demikian, notaris akan menjamin isi perjanjian perkawinan sesuai dengan apa yang tercantum dalam minuta aktanya. Kemudian kepada para pihak diberikan salinan akta yang sama bunyinya dengan minuta akta dan berlaku sebagai alat bukti yang mempunyai kekuatan pembuktian yang sempurna. Oleh karena itu, dalam akta notaris terdapat jaminan kepastian hukum mengenai isi perjanjian terhadap pihak ketiga. ${ }^{24}$ Perjanjian perkawinan harus didaftarkan untuk memenuhi prinsip publisitas agar orang lain dapat mengetahui dan tunduk pada perjanjian serta mengikatnya dalam perbuatan hukum yang akan dilakukannya.

Berdasarkan Pasal 29 UU Perkawinan, Permenag RI No. 20/2019 maupun Surat Edaran 472.2/5876/Dukcapil maka perjanjian perkawinan agar dapat mengikat bagi pihak ketiga maka perjanjian perkawinan tersebut harus dicatatkan ke Kepala KUA Kecamatan/PPN LN pada Akta Nikah dan Buku Nikah. Pada dasarnya suatu perjanjian perkawinan dibuat dengan kesepakatan para pihak yang akan melaksanakan perkawinan atau sedang dalam suatu perkawinan, perjanjian tersebut dibuat dalam bentuk akta notaris lalu dicatatkan pada Dinas Kependudukan dan Catatan Sipil. Menurut Pasal 23 Permenag RI No. 20/2019, dibuatkannya perjanjian perkawinan wajib dalam bentuk akta notaris agar dapat dicatatkan pada Kepala KUA Kecamatan/PPN LN maka Perjanjian Perkawinan tersebut akan mengikat pihak ketiga. Hal ini juga ditegaskan dalam Kompilasi Hukum Islam pada Pasal 50 yang menyebutkan bahwa perjanjian perkawinan mengenai harta, mengikat kepada para pihak dan pihak ketiga, terhitung mulai tanggal dilangsungkannya perkawinan di hadapan pegawai pencatat nikah. ${ }^{25}$

Apabila suatu perjanjian perkawinan dibuat dalam bentuk di bawah tangan dan lalu dibuatkan akta penegasan atas perjanjian perkawinan tersebut oleh notaris maka, akta penegasan perjanjian perkawinan tersebut tidak dapat mengikat pihak ketiga karena akta penegasan bukan sebagai perwujudan dari prinsip publisitas yang mengakibatkan mengikat pihak ketiga. Pada Pasal 29 UU

\footnotetext{
${ }^{24}$ Erdhyan Paramita, Irnawan Darari, Op.Cit.[35].

${ }^{25}$ Libertus Jehani, Perkawinan Apa Resiko Hukumnya? (Forum Sahabat 2008).[78].
} 
Perkawinan tidak mengharuskan pembuatan perjanjian perkawinan dibuat dalam bentuk akta notariil, Perjanjian perkawinan harus dibuat dalam bentuk tertulis, yang artinya dapat berupa akta notaril ataupun di bawah tangan. ${ }^{26} \mathrm{Hal}$ ini berbeda dengan kekuatan hukum perjanjian perkawinan menurut Putusan MK No. 69/ PUU-XII/2015, Pasal 22 Permenag RI No. 20/2019 dan Surat Edaran 472.2/5876/ Dukcapil, Perjanjian perkawinan harus menggunakan akta notariil.

Jadi, kekutaan hukum bilamana mengacu pada Pasal 22 Permenag RI No. 20/2019 dan Surat Edaran 472.2/5876/Dukcapil maka Perjanjian Perkawinan yang dibuat dan oleh Notaris $X$ tidak memenuhi persyaratan pencatatan pelaporan perjanjian perkawinan karena akta perjanjian perkawinan yang seharusnya adalah dalam bentuk akta notariil namun notaris $\mathrm{X}$ dan Tuan Z-Nyonya $\mathrm{R}$ membuat perjanjian perkawinan tersebut dengan perjanjian di bawah tangan dan akta penegasan, yang dimana otomatis tidak mengikat pihak ketiga, sebab tidak terpenuhinya Prinsip publisitas yang merupakan kewajiban membuka informasi tersebut kepada publik. Perjanjian perkawinan yang dibuat dengan perjanjian di bawah tangan tidak sah karena tidak memenuhi syarat materiil dan formil dalam Perjanjian Perkawinan sehingga tidak dapat mengikat pihak ketiga.

Mengenai akibat hukum, seperti yang kita ketahui bahwa perjanjian pada umumnya menimbulkan akibat hukum bagi pihak yang membuatnya, maupun terhadap pihak ketiga yang berkepentingan, maka hal ini sama dengan timbulnya akibat hukum bagi perjanjian perkawinan. Akibat hukum apabila tak terlaksananya prinsip publisitas pada perjanjian perkawinan pada harta bersama perkawinan yaitu jelas tidak adanya pemisahan harta bersama yang seharusnya diatur dalam Perjanjian Perkawinan, melainkan harta dalam perkawinan tersebut menjadi harta bersama. Sesuai dengan prinsip lahirnya perjanjian yaitu Prinsip konsensualisme yang menyatakan bahwa perjanjian lahir sejak saat tercapainya kata sepakat antara para pihak, maka dengan sendirinya perjanjian perkawinan mengikat pihak yang membuatnya saat keduanya sepakat tentang perjanjian perkawinan yang dibuat,

${ }^{26}$ Trisadini Prasastinah Usanti, Ghansham Anand, Op.Cit.[95]. 
baik di daftarkan ataupun tidak. ${ }^{27}$ Maka didaftarkan ataupun tidak, perjanjian perkawinan yang telah dibuat memiliki akibat hukum yang tetap mengikat bagi suami isteri yang telah bersepakat membuatnya, akan tetapi bila tidak didaftarkan perjanjian perkawinan tersebut maka tidak mengikat pihak ketiga.

Dengan demikian, kedua belah pihak tetap terikat dengan kesepakatan yang terdapat dalam Perjanjian Perkawinan tersebut. Lalu, pada saat melakukan proses jual beli tanah atau pengalihan harta perkawinan akan tetap membutuhkan persetujuan pasangan kawin. Selain itu akibat hukum lainnya yaitu, apabila terjadinya kepailitan tanpa adanya perjanjian perkawinan, atas putusan kepailitan yang dijatuhkan kepada suami isteri terhadap harta bersamanya melalui Putusan Pengadilan akan dinilai sebagai kepailitan bersama, sesuai dengan ketentuan pada Pasal 64 ayat (1) Undang-Undang Nomor 37 tahun 2004 tentang Kepailitan dan Penundaan Kewajiban Pembayaran Utang (UU Kepailitan dan PKPU) yang menyatakan, Kepailitan suami isteri yang kawin dalam persatuan harta, diperlakukan sebagai kepailitan persatuan harta tersebut. ${ }^{28}$ Sehingga keberadaan akta penegasan disini bukan patokan sebagai Perjanjian Perkawinan secara sah, karena kriterianya sudah berbeda dengan sebagaimana yang dimaksudkan UU Perkawinan maupun Permenag RI No. 20/2019 dan Surat Edaran 472.2/5876/ Dukcapil maka dapat dikatakan bahwa akta penegasan ini tidak mempunyai kekuatan hukum yang mengikat bagi pihak ketiga, hanya saja mengikat untuk para pihak yang membuatnya sebagaimana yang dikenal dengan prinsip privity of contract yang diatur dalam Pasal 1340 BW.

\section{Kesimpulan}

Perjanjian perkawinan yang dibuat di bawah tangan kemudian dibuatkan akta penegasan oleh notaris maka akta penegasan tersebut tidak memenuhi prinsip publisitas sebagaimana yang telah ditentukan dalam UU Perkawinan,

\footnotetext{
${ }^{27}$ Claudia Verena Maudy Sridana, I Ketut Suardita, 'Akibat Hukum Terhadap Perjanjian Perkawinan Yang Tidak Didaftarkan’ (2018) 6 Journal Kerthasemaya.[6].

${ }^{28}$ Putu Indi Apriyani, 'Akibat Hukum Kepailitan Suami/Isteri Terhadap Harta Bersama Suami-Isteri Tanpa Perjanjian Kawin' (2016) 4 Kertha Semaya : Journal Ilmu Hukum.[3].
} 
karena dalam salah satu syarat keabsahan perjanjian perkawinan harus dilakukan pendaftaran pada pegawai pencatatan perkawinan agar mengikat pihak ketiga sehingga akta penegasan perjanjian perkawinan yang tersebut tidak mengikat pihak ketiga. Agar dapat memenuhi Prinisip publisitas dan mengikat pihak ketiga, Perjanjian Perkawinan harus didaftarkan. Bagi yang beragama Islam dilakukan pendaftaran di KUA Kecamatan/PPN LN, sedangkan bagi yang beragama NonIslam didaftarkan di Dinas Kependudukan dan Pencatatan Sipil dengan syarat pembuatan perjanjian perkawinan dalam bentuk akta notariil.

Akibat hukum dari akta penegasan perjanjian perjanjian yang tidak memenuhi prinsip publisitas dan tidak mengikat pihak ketiga maka harta kekayaan suami isteri tetap mengacu pada pemisahan harta sebagaimana diatur pada UU Perkawinan yaitu adanya harta Bersama dan harta bawaan dalam perkawinan. Maka bilamana bersangkutan dengan perbuatan hukum yang salah satunya seperti menjaminkan atau menjual harta Bersama baik yang dilakukan dari salah satu pihak yaitu suami atau isteri maka diperlukan adanya persetujuan dari lawan kawinnya (spouse letter).

\section{Daftar Bacaan}

\section{Buku}

Kamus Besar Bahasa Indonesia (Balai Pustaka 2001).

Libertus Jehani, Perkawinan Apa Resiko Hukumnya? (Forum Sahabat 2008).

Moch. Isnaeni, Hukum Perkawinan Indonesia (Refika Aditama 2016).

Tobing Lumban, Peraturan Jabatan Notaris (Erlangga 1983).

Trisadini Prasastinah Usanti dan Ghansham Anand, Hukum Keluarga dan Hukum Perkawinan (Revka Prima Media 2019).

\section{Tesis}

Amalia, 'Peran Notaris Dalam Proses Perubahan Anggaran Dasar Perseroan Terbatas' Tesis (UI 2009). 


\section{Jurnal}

Christian Supandi, 'Pembagian Harta Bersama Akibat Perceraian Menurut Undang-Undang Nomor 1 Tahun 1974’ (2019) 3 Jurnal Lex Privatum.

Claudia Verena Maudy Sridana, I Ketut Suardita, 'Akibat Hukum Terhadap Perjanjian Perkawinan Yang Tidak Didaftarkan' (2018) 6 Journal Kerthasemaya.

Erdhyan Paramita, Irnawan Darori, 'Akibat Hukum Perjanjian Perkawinan Yang Tidak Disahkan Oleh Pegawai Pencatat Perkawinan' (2017) 4 Jurnal Repertorium.

Evi Djuniarti, 'Hukum Harta Bersama Ditinjau Dari Perspektif Undang-Undang Perkawinan Dan KUH Perdata' (2017) 17 Jurnal Penelitian Hukum De Jure.

I Ketut Tjukup, I Wayan Bela Siki Layang, Nyoman A. Martana, I Ketut Markeling, Nyoman Satyayudha Dananjaya, I Putu Rasmadi Arsha Putra, Komang Widiana Purnawan, Made Diah Sekar Mayang Sari, Ketut Nihan Pundari dan Putu Ayu Ratih Tribuana, 'Akta Notaris (Akta Otentik) Sebagai Alat Bukti Dalam Peristiwa Hukum Perdata' (2016) 1 Jurnal Ilmiah Prodi Magister Kenotariatan.

Liky Faizal, 'Harta Bersama Dalam Perkawinan' (2015) 8 Jurnal Pengembangan Masyarakat Islam.

Meitinah,' Kekuatan Pembuktian Akta Di Bawah Tangan Yang Telah Memperoleh Legalisasi Dari Notaris' (2006) 36 Jurnal Hukum \& Pembangunan.

Oscar I Roos dan Anita Mackay, 'The Evolutionary Interpretation Of Treaties And The Right To Marry: Why Article 23 (2) Of The ICCPR Should Be Reinterpreted To Encompass Same-Sex Marriage' (2017) 49 Journal ICCPR.

Putu Indi Apriyani, 'Akibat Hukum Kepailitan Suami/Isteri Terhadap Harta Bersama Suami-Isteri Tanpa Perjanjian Kawin’ (2016) 4 Kertha Semaya : Journal Ilmu Hukum.

Sarizal, Darmawan, dan Mahfud Abdullah, 'Kedudukan Perjanjian Kawin Terhadap Pemisahan Harta Bersama Setelah Dilaksanakannya Perkawinan Kaitannya Dengan Putusan Mahkamah Konstitusi Nomor 69/PUUXIII/2015 Tentang Waktu Pembuatan Perjanjian Kawin'(2019) 3 Syiah Kuala Law Journal.

Sylvia Widjaja, 'Aneka Permasalahan Mengenai Perjanjian Kawin Pengesahan atau Pencatatan' (2015) 7 Jurnal Dialogia Iuridica. 
Umi Setyawati, Amin Purnawan, 'Akta Penegasan Keterangan Waris Sebagai Pengganti Surat Keterangan Waris Dalam Pengurusan Balik Nama Waris di Kantor Pertanahan Kota Semarang' (2018) 5 Jurnal Akta.

Yudha Tri Dharma Iswara, I Ketut Markeling, 'Kekuatan Pembuktian Surat Di Bawah Tangan Dalam Akta Perjanjian Jual-Beli' (2016) 4 Journal Ilmu Hukum Kertha Semaya.

\section{Laman}

KlikLegal.Com, 'Ini Dua Syarat Agar Perjanjian Perkawinan Bisa Dicatat Di Dukcapil' (KlikLegal.Com, 2017) <https://kliklegal.com/ini-dua-syarat-agarperjanjian-perkawinan-bisa-dicatat-di-dukcapil/>.

Ratna D. E. Sirait, 'Kedudukan Harta Dalam Perkawinan Campuran Ditinjau Dari Undang-Undang No. 1 Tahun 1974' <http://www.ust.ac.id/assets/file/ penelitian/ratna-d-e-sirait-sh-m-hum_1551070153.pdf>.

\section{Perundang-Undangan}

Undang-Undang Nomor 1 Tahun 1974 tentang Perkawinan (Lembaran Negara Republik Indonesia Tahun 1974 Nomor 1, Tambahan Lembaran Negara Republik Indonesia Nomor 3019).

Undang-Undang Nomor 2 Tahun 2014 Tentang Perubahan Atas Undang-Undang Nomor 30 Tahun 2004 Tentang Jabatan Notaris (Lembaran Negara Republik Indonesia Tahun 2004 Nomor 117, Tambahan Lembaran Negara Republik Indonesia Nomor 4432).

Undang-Undang Nomor 16 Tahun 2019 Perubahan Atas Undang-Undang Nomor 1 Tahun 1974 tentang Perkawinan. (Lembaran Negara Republik Indonesia Tahun 2019 Nomor 186, Tambahan Lembaran Negara Republik Indonesia Nomor 6401).

Instruksi Presiden Republik Indonesia Nomor 1 Tahun 1991 Tentang Penyebarluasan Kompilasi Hukum Islam.

Peraturan Pemerintah Nomor 9 Tahun 1975 tentang pelaksanaan Undang-Undang Nomor 1 Tahun 1974 tentang Perkawinan.

Peraturan Menteri Agama Republik Indonesia Nomor 20 Tahun 2019 Tentang Pencatatan Pernikahan.

Surat Direktur Jendral Bimbingan Masyarakat Islam Kementerian Agama Nomor B: 2674/DJ.III/KW.00/9/2017 perihal Pencatatan Perjanjian Perkawinan. 
Surat Edaran 472.2/5876/Dukcapil Tentang Pencatatan Pelaporan Perjanjian Perkawinan.

\section{Putusan Mahkamah Konstitusi}

Putusan Mahkamah Konstitusi Nomor 69/PUU/XIII/ 2015.

How to cite: Raden Ajeng Cendikia Aurelie Maharani, 'Akta Penegasan Perjanjian Perkawinan Kaitannya dengan Pemenuhan Prinsip Publisitas’ (2021) Vol. 4 No. 2 Notaire. 
312 | Raden Ajeng: Akta Penegasan Perjanjian...

--Halaman ini sengaja dikosongkan-- 